\title{
Diabetes and play therapy
}

\author{
Sanjay Kalra, Shuchy Chugh ${ }^{1}$, P. Dinakaran ${ }^{1}$ \\ Department of Endocrinology, Bharti Hospital and BRIDE, Karnal, Haryana, ${ }^{1}$ Novo Nordisk Education Foundation, Bangalore, Karnataka, India
}

\section{A B S T R A C T}

Context: Type I diabetes is a lifelong disorder needing $24 \times 7 \times 365$ care and attention. In these children, adherence to prescribed medical regimens and monitoring on a continuous basis is one of the most challenging problems faced by the medical community. Self-management becomes very essential for ensuring good outcomes, since psychosocial factors also play a crucial role in regimen adherence and glycemic control. Aim: This article aims to describe the utility of play therapy in diabetes management. Play therapy is a useful approach that can help in establishing a dynamic interpersonal relationship between the child and the therapist in a playful unconventional manner, supporting in their learning process for self-management. Materials and methods: This communication reviews available literature on play therapy, and describes examples of play therapy used in a mulitnational programme. The changing diabetes in children program focused at reaching out to the economically underprivileged children with type I diabetes, has implemented two useful play therapy tools to help the type I child learn to take insulin injections and understand the basic do's and don'ts for proper diabetes management. Conclusion: Play-therapy is useful in making the difficult task of managing diabetes interesting and easy.

Key words: Diabetes education tools, good habits, insulin taking site rotation, insulin taking technique, motivation, Novo Nordisk teaches to take insulin doll, play therapy, psychosocial factors, snakes and ladders, type I diabetes

\section{INTRODUCTION}

Type 1 diabetes is one of the most common chronic diseases in children and adolescents. The last 30 years have seen a substantial increase in reported cases of diabetes in children. 78,000 new cases are reported each year in children world-wide. Of the estimated $490,000^{[1]}$ children living with type 1 diabetes, $24 \%$ come from the European region and $23 \%$ from the South-East Asia region. India is the largest contributor to this number and also to mortality attributable to diabetes in children in South-East Asia.

Everyone with type 1 diabetes requires insulin from the beginning. The impact of diabetes is very huge especially when it strikes in childhood or adolescence, in fact, many children die because of undiagnosed diabetes. On

\begin{tabular}{|l|l|}
\hline \multicolumn{2}{|c|}{ Access this article online } \\
\hline Quick Response Code: & Website: \\
\hline & www.josh.net \\
\hline & \\
\hline & \\
\hline
\end{tabular}

the other hand if properly treated, children with type 1 diabetes can grow like normal individuals, be productive, fertile and long-lived adults. It is therefore essential that childhood diabetes is recognized as early as possible and treated adequately.

\section{ChAllenges FOR CHILDREN WITH DIABETES}

Children and adolescents face significant burdens on health and quality-of-life (QOL) associated with the early appearance of diabetes. Taking insulin and other medication, checking blood glucose levels, balancing activity and food choices adds to the demanding challenges of physical and emotional growth. Mostly children and their families find it difficult to cope emotionally when diabetes is detected. This trauma and the burden are most when the child is very young. The needs of children with diabetes change as they grow. Families need help to cope with the condition while learning about diabetes and its management. It is essential for the child to learn to take the self-insulin injection, monitor sugar levels at home and adjustments in diet and exercise to keep blood sugar levels near normal. Along with the $24 \times 7 \times 365$ burden of diabetes self-management, children with diabetes face discrimination and sometimes also limited social 
relationships. Psychosocial factors have a major influence in regimen adherence and glycemic control.

Type 1 diabetes is a lifelong disorder. Observance to medical treatment and management of diabetes on regular and continuous basis is one of the most challenging

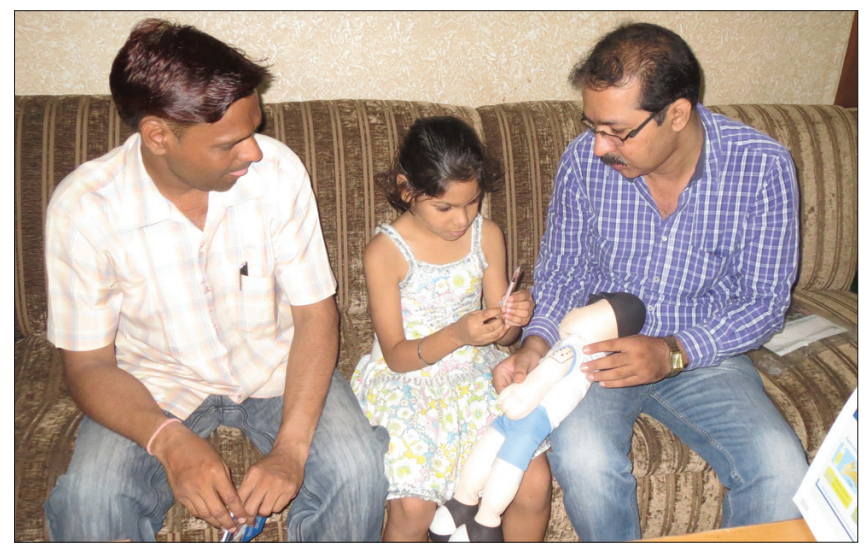

Figure 1: Diabetes educator teaching a child to take insulin

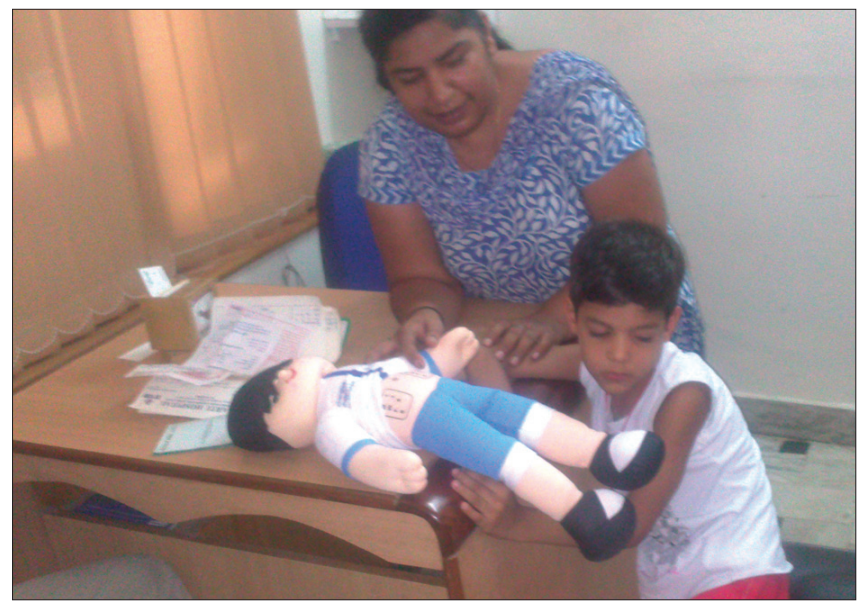

Figure 2: Diabetes educator trying to address a non-cooperative child

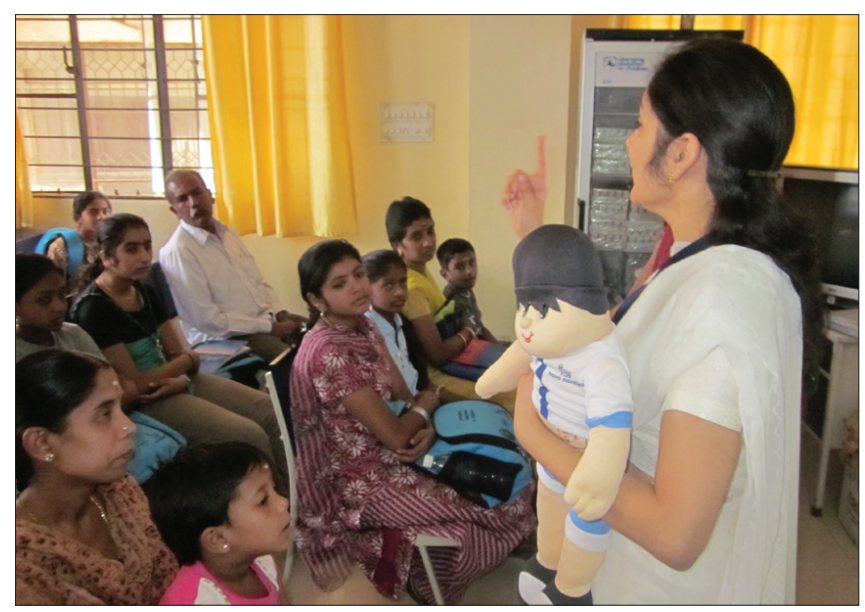

Figure 3: In group education session problems faced by the medical community. Education and counseling about diabetes and its management is very important. Initially, it is a means of sharing responsibility between health care professional, the child and its family. In the long run, this understanding about diabetes and its self-management (whether positive or negative) impacts the whole life and future of child with type 1 diabetes. To be effective, diabetes education has to be carried out in a child - friendly way.

\section{PLAY THERAPY}

Is defined as a dynamic interpersonal relationship between a child and a therapist to fully express and explore self (feelings, thoughts, experiences and behaviors) through the child's natural medium of communication, "play" (Landreth). ${ }^{[2]}$ As stated by Billington, play is a natural function of any child, whether well or sick. ${ }^{[3]}$ In play, children are given the opportunity to play out feelings and problems so that they become more manageable (Axline) and thus in more control of their lives. ${ }^{[4]}$

Toys are not only means of fun and entertainment, but also means of physical and mental development of the child and important elements of influencing the future society. Since ages, traditional toys have been used in India, to teach ethical and moral values to children. Dolls and puppets were not casual play things, but were used to narrate stories and images to teach children skills and values that they will use as adults. They were intrinsically related to the social and religious rites of the local community and thus helped in building right character for a child.

No doubt, play therapy allows children to gain maximum opportunity to control or understand diseases and medical procedures while remaining a child. Other benefits to the child include:

- Breaking the silence between child and doctor or educator.

- Creating friendship rather than strict doctor patient relationship which has been taught knowingly or unknowingly to the child.

- Clarity in goal setting ensuring true feedback, goal rehearsal and adequate reinforcement many times before the child can learn to do it independently.

- Reduction of stress of unknown and being alone for the child.

- Enabling expression of child's feeling and true reactions.

\section{EVIDENCE BASE}

Play therapy has been utilized earlier at many instances [Table 1]: 


\begin{tabular}{|c|c|c|c|c|c|c|}
\hline Name & Author & Year & $\begin{array}{l}\text { Type of the } \\
\text { manuscript }\end{array}$ & $\begin{array}{l}\text { Subject } \\
\text { population }\end{array}$ & Play tool used & Results \\
\hline $\begin{array}{l}\text { Educational video } \\
\text { game for juvenile } \\
\text { diabetes: results of } \\
\text { a controlled trial|[5] }\end{array}$ & $\begin{array}{l}\text { S. J. Brown, D. } \\
\text { A. Lieberman, } \\
\text { B. A. Gemeny, } \\
\text { Y. C. Fan, D. M. } \\
\text { Wilson and D. } \\
\text { J. Pasta }\end{array}$ & 1997 & $\begin{array}{l}\text { Original } \\
\text { manuscript }\end{array}$ & $\begin{array}{l}\text { Study } \\
\text { participants } \\
\text { were patients } \\
\text { aged } 8 \text {-16 from } \\
\text { two separate } \\
\text { diabetes clinics }\end{array}$ & $\begin{array}{l}\text { Packy and } \\
\text { Marlon-Video } \\
\text { game }\end{array}$ & $\begin{array}{l}\text { The finding in this study indicate that } \\
\text { there was improvement in the treatment } \\
\text { group in terms of diabetes related self- } \\
\text { efficacy, communication with parents } \\
\text { about diabetes and self-care behaviors } \\
\text { and decrease in unscheduled urgent } \\
\text { doctor visits }\end{array}$ \\
\hline $\begin{array}{l}\text { The efficacy of } \\
\text { intensive individual } \\
\text { play therapy for } \\
\text { children diagnosed } \\
\text { with IDDM } \\
\text { [6] }\end{array}$ & $\begin{array}{l}\text { Elizabeth } \\
\text { Murphy Jones }\end{array}$ & 2000 & $\begin{array}{l}\text { Dissertation } \\
\text { prepared for } \\
\text { the degree } \\
\text { of doctor of } \\
\text { philosophy }\end{array}$ & $\begin{array}{l}\text { Subjects } \\
\text { were selected } \\
\text { from children } \\
\text { attending Camp } \\
\text { Sweeney, a } \\
\text { summer camp } \\
\text { for children } \\
\text { with diabetes } \\
\text { located in } \\
\text { Gainesville }\end{array}$ & $\begin{array}{l}\text { Fully equipped } \\
\text { doctor's kit, } \\
\text { syringes and } \\
\text { blood glucose } \\
\text { monitoring } \\
\text { equipment. } \\
\text { Toys, dolls }\end{array}$ & $\begin{array}{l}\text { Results of this study indicate that } \\
\text { intensive play therapy may be an } \\
\text { effective intervention for children } \\
\text { diagnosed with IDDM. Qualitative } \\
\text { observations and progress noted in play } \\
\text { therapy reveal that young children with } \\
\text { IDDM* have the capability to address } \\
\text { and resolve issues of anxiety, depression } \\
\text { and other emotional issues related to } \\
\text { their diabetes in play therapy }\end{array}$ \\
\hline $\begin{array}{l}\text { Effective } \\
\text { intervention or } \\
\text { child's play? A } \\
\text { review of video } \\
\text { games for diabetes } \\
\text { education }{ }^{[7]}\end{array}$ & $\begin{array}{l}\text { Jonathan } \\
\text { DeShazo, } \\
\text { Ph.D., M.P.H.,1 } \\
\text { Lynne Harris, } \\
2 \text { and Wanda } \\
\text { Pratt, Ph.D.3 }\end{array}$ & 2010 & Review & & & $\begin{array}{l}\text { Video games for diabetes education } \\
\text { show potential as effective educational } \\
\text { interventions. Evaluations have shown } \\
\text { positive outcomes in knowledge, disease } \\
\text { management adherence, and clinical } \\
\text { outcomes }\end{array}$ \\
\hline $\begin{array}{l}\text { Importance of } \\
\text { using therapeutic } \\
\text { toys in care of } \\
\text { children with } \\
\text { diabetes type } 1^{[8]}\end{array}$ & $\begin{array}{l}\text { Déa Silvia } \\
\text { Moura da } \\
\text { Cruz, Neusa } \\
\text { Collet, Daniela } \\
\text { Karina Antão } \\
\text { Marques4 }\end{array}$ & 2012 & $\begin{array}{l}\text { Clinical } \\
\text { case report } \\
\text { article }\end{array}$ & & $\begin{array}{l}\text { Doll and insulin } \\
\text { syringe }\end{array}$ & $\begin{array}{l}\text { The use of the therapeutic toy technique } \\
\text { favored greater interaction of the nurse } \\
\text { with the child and the family, allowing the } \\
\text { adequate assimilation of the situation } \\
\text { experienced by accepting to perform } \\
\text { the procedure required on the doll } \\
\text { (delivery of insulin) }\end{array}$ \\
\hline $\begin{array}{l}\text { Use of play therapy } \\
\text { in educating } \\
\text { asthmatic and } \\
\text { diabetic pediatric } \\
\text { patients: A pilot } \\
\text { clinical project at } \\
\text { a private tertiary } \\
\text { setting in Karachi, } \\
\text { Pakistan }\end{array}$ & $\begin{array}{l}\text { Hirani Shela } \\
\text { Akbar Ali }\end{array}$ & 2013 & Original & $\begin{array}{l}\text { Pediatric } \\
\text { inpatient and } \\
\text { outpatient } \\
\text { patients of a } \\
\text { private tertiary } \\
\text { care hospital } \\
\text { in Karachi, } \\
\text { Pakistan }\end{array}$ & $\begin{array}{l}\text { Dolls and play } \\
\text { therapy kit }\end{array}$ & $\begin{array}{l}\text { After play therapy sessions, it was } \\
\text { noticed that asthmatic and newly } \\
\text { diagnosed diabetic children who were } \\
\text { previously fearful, anxious, and had no } \\
\text { knowledge about their disease process, } \\
\text { were able to verbalize about their disease } \\
\text { and demonstrate the correct technique } \\
\text { of inhaler and insulin administration on } \\
\text { dolls and then on self }\end{array}$ \\
\hline
\end{tabular}

\section{Changing Diabetes in Children (CDiC) PROGRAM}

In an attempt to address the critical gap in the management of diabetes in India, Novo Nordisk Education Foundation, in collaboration with the International Society for Pediatric and Adolescent Diabetes and Roche had launched CDiC program with the objective of giving children below the poverty line access to comprehensive diabetes care and management. As part of the program, these 4000 children are provided with free insulin, diagnostic tests, monitoring and diabetes education.

\section{CDIC AND PLAY THERAPY - NOVO NORDISK TEACHES TO TAKE INSULIN (NOTTI) DOLL}

NOTTI doll is a soft, unbreakable, easy to carry, conveniently sized educational toy, designed as a diabetes education tool. It is being given to children with diabetes participating in the $\mathrm{CDiC}$ India program. The purpose is to help the children learn how to take insulin. To make NOTTI, look similar in appearance to any other toy, insulin taking sites and marking are covered by the dress worn by it.

\section{Importance of correct insulin taking technique}

Children with type 1 diabetes need to take insulin on continuous basis. Learning correct insulin technique is very important for children as it is essential for achieving good glycemic control. Secondly, if the child repeatedly takes insulin at one place it can cause lipoatrophy and lipodystrophy leading to fluctuations in blood sugar levels. Thus, wrong insulin taking technique and in turn high blood sugar levels can affect the whole life of a child. 
Uses

NOTTI has many uses, namely it helps to [Figures 1-3]:

1. Initiate conversation.

2. Understand about taking insulin injection.

3. Understand sites for taking insulin.

4. Understand rotation of insulin site.

5. Practice taking injection.

6. Encourage self-injection.

7. Understand basic anatomy of human body.

8. Express symptomatology (e.g., child: "I have a pain in my tummy." Dr.: "Tell me where in the tummy. Show me on your doll").

9. Encourage good self-care practices (take care of NOTTI, take care of yourself) and

10. As a gift to the child, since all children love toys.

\section{Qualitative research}

Along with distribution to every child enrolled in $\mathrm{CDiC}$ program, NOTTI because of its popularity was given to various other type 1 clinics and camps all over India. An 8-year-old child with diabetes told, "my NOTTI doll is my best friend, she lives in my pillow." According to another child, "if NOTTI has no tear and no fear of injection, so, why should I?" Diabetes educator at CDiC center Pune wrote. "The doll was a complete hit and children would love to take one. It did make it very easy for us to teach the injection sites to parents and children using it." A Father of a child with type 1 diabetes said, "NOTTI depicts smiling face which shows we should be always positive and have good attitude." According to Dr. Sanjay Kalra, CDiC Centre Director, Karnal, "it helps break the ice; brings a smile to the child's face.” Dr. Rishi Shukla, CDiC Center Director, Kanpur, describes NOTTI "as a playful way of learning insulin injection sites."

\section{Translational research}

NOTTI has also been used as a useful tool for, "insulin injection sites" education for para medical health workers and people for type 2 diabetes in the state of Bihar and Gujarat for changing diabetes barometer project. It has also been used in diabetes video made for the BOP project, to dispel the myth that, taking insulin is a very difficult task.

\section{SNAKES AND LADDERS}

Snakes and ladders, is another diabetes education tool, which was designed from the old conventional board game. While playing this board game, the child learns the basic do's and don'ts of diabetes. In this game each square represents a habit, some of them are applicable for all children and few are applicable specifically for children with type 1 diabetes. The square at the base of a ladder is represented by a good habit/the do's, which, like ladders will take you higher/ahead in life. On the contrary, the square at the head of a snake is represented by a bad habit/ the don'ts, like snakes bad habits create hindrance in moving ahead. A version of snakes and ladders game was also designed at Bharti Hospital, Karnal, India to improve motivation and concordance with diabetes therapy and was highly appreciated with children with diabetes. ${ }^{[10]}$

\section{Importance of comprehensive education}

A diagnoses with type 1 diabetes, not only involves taking insulin but also following a balanced diet, exercise and monitoring blood sugar levels to ensure best use of the injected insulin. Comprehensive diabetes education is essential for every child with type 1 diabetes to achieve maximum number of blood sugar readings in the near normal range, in order to have a good QOL and reduce the risk of complications of diabetes.

Use

Snakes and ladders game offers multiple benefits, namely:

1. Motivating the child for self-care.

2. Reinforcing correct diabetes care essentials.

3. Help them see the consequences of their various actions.

4. Influence friends and siblings to understand diabetes.

5. Creating a bond between, doctor, child and society.

\section{Qualitative research}

Apart from English, "snakes and ladders" game has been translated in 10 Indian languages. Along with distribution to every child enrolled in $\mathrm{CDiC}$ program, because of its usage and popularity I has been given to various other type 1 clinics and camps all over India. According to a parent of a child with type 1 diabetes, "this is not a game for my child only, but it's a game for our whole family and we love to play and learn from it." Diabetes Educator at Kanpur says, "this game should be part of every school program."

According to Dinakaran P, project manager CDiC, "in managing type 1 diabetes, "self-help" is the best help we thought these toys (NOTTI/snake and ladder) will aid in helping these children learn in a playful manner, making them self-reliant and support in managing their diabetes better."

\section{CONCLUSION}

NOTTI and snakes and ladders are good examples, showcasing how; play therapy can be useful, not only for children, but also for adults in making the difficult task of managing diabetes interesting and simpler. 


\section{REFERENCES}

1. The Global IDF/ISPAD Guideline for Diabetes in Childhood and Adolescence. Diabetes Atlas $-5^{\text {th }}$ Edition.

2. Landreth. Play Therapy: The Art of the Relationship. $2^{\text {nd }}$ ed. Publication date 1 May, 1991. p. 16.

3. Billington GF. Play program reduces children's anxiety, speeds recoveries. Mod Hosp 1972;118:90-2.

4. Axline VM. Play Therapy. New York: Ballantine Books. 1969.

5. Available from: http://www.ncbi.nlm.nih.gov/pubmed/9183781. [Last accessed date $7^{\text {th }}$ Aug 2013].

6. Available from: http://digital.library.unt.edu/ark:/67531/ metadc2636/m2/1/high_res_d/Dissertation.pdf. [Last accessed date $7^{\text {th }}$ Aug 2013].

7. Available from: http://www.ncbi.nlm.nih.gov/pubmed/20807119. [Last accessed date $7^{\text {th }}$ Aug 2013].
8. Déa Silvia Moura da Cruz, Neusa Collet, Daniela Karina Antão Marques. Importance of using therapeutic toys in care of children with diabetes type 1. J Nurs UFPE/Rev Enferm UFPE 2012;6:858.

9. Hirani Shela Akbar Ali. Use of Play Therapy in Educating Asthmatic and Diabetic Pediatric Patients: A Pilot Clinical Project at a Private Tertiary Setting in Karachi, Pakistan. Int J Nurs Care 2013;1:83.

10. Kalra S, Nagpal S, Kalra B. Effectiveness of educational intervention with snakes and ladders board game in children with type 1 diabetes. Pediatr Diabetes 2007;8:29.

How to cite this article: Kalra S, Chugh S, Dinakaran P. Diabetes and play therapy. J Soc Health Diabetes 2014;2:40-4.

Source of Support: Nil. Conflict of Interest: None declared. 